\title{
Kualifikasi Calon Legislatif dalam Sistem Proporsional Terbuka Menurut Pandangan Fiqih Siyasah*
}

\author{
Mukhtori, ${ }^{1}$ Abdur Rahim ${ }^{2}$ \\ Institut Agama Islam Al Zaytun Indonesia \\ d \\ $\underline{10.15408 / \text { sjsbs.v7i9.16594 }}$
}

\begin{abstract}
:
Elections in Indonesia are considered the most democratic because they can elect legislative candidates directly. The candidate is clearly displayed in the photo. Because it can be seen directly by voters, legislative candidates need qualifications. These qualifications do not only rely on clever speech, handsome or beautiful, rich, popular, or have a large following. Qualifications of legislative candidates according to the view of fiqh siyasah include credibility and balance of the nature of shiddiq, amanah, tablig, fathonah, extensive knowledge which are knotted in basthothan fil ilmi wa al jismi, and have opinions the strong and wisdom wisdom. This open proportional system according to the view of fiqh siyasa was once carried out during the time of the Prophet Muhammad and al-Khulafaur Rasyidin in the election of ahlul halli wa al aqdi.
\end{abstract}

Keywords: system, proportional, qualifications, siyasah

\begin{abstract}
Abstrak:
Pemilihan Umum di Indonesia dinilai paling demokratis karena dapat memilih calon anggota legislatif secara langsung. Calon tersebut terpampang dalam foto secara jelas. Karena dapat dilihat langsung oleh pemilih, maka calon legislatif memerlukan kualifikasi. Kualifikasi tersebut jangan hanya mengandalkan pandai berpidato, tampan atau cantik, kaya, populer, maupun memiliki pengikut yang banyak. Kualifikasi calon legislatif menurut pandangan fiqih siyasah diantaranya mempunyai kredibilitas dan keseimbangan sifat shiddiq, amanah, tablig, fathonah, berpengetahuan yang luas yang tersimpul di dalam basthothan fil ilmi wa al jismi, serta mempunyai pendapat yang kuat dan hikmah kebijaksanaan. Sistem proporsional terbuka ini menurut pandangan fiqih siyasah pernah dijalankan pada masa Nabi Muhammad saw. dan al-Khulafaur Rasyidin dalam pemilihan ahlul halli wa al aqdi.
\end{abstract}

Kata kunci: sistem, proporsional, kualifikasi, siyasah

\footnotetext{
* Received: April 19, 2020, Revised: July 21, 2020, Published September 3, 2020.

${ }^{1}$ Mukhtori adalah Peneliti pada Program Studi Hukum Tatanegara Fakultas Syariah, Institut Agama Islam Al-Zaytun Indonesia, alamat email: mukhtori71@gmail.com.

${ }^{2}$ Abdur Rahim adalah Dosen Institut Agama Islam Al Zaytun Indonesia, Mekarjaya, Gantar, Indramayu, Jawa Barat, alamat email: abdur.rahim@iai-alzaytun.ac.id.
} 


\section{A. PENDAHULUAN}

Indonesia merupakan negara demokrasi yang sedang berkembang. Perkembangan demokrasi di Indonesia sudah mengalami perubahan dari demokrasi tidak langsung menjadi demokrasi langsung. Perubahan tersebut mengarah kepada penyempurnaan sistem demokrasi di Indonesia. Sistem demokrasi di Indonesia menggunakan sistem pemilihan umum untuk memilih pemimpin sebagai wakil rakyat.

Pemilihan umum di Indonesia telah mengalami tiga babak pemilihan yaitu pemilihan umum pada masa orde lama, pemilihan umum masa orde baru dan pemilihan umum masa reformasi. Dari ketiga masa tersebut, masa kini lah yang dinilai paling demokratis dalam sistem pemilihan umum. Walaupun dalam pelaksanaannya masih terdapat kekurangan. Kekurangan atau kelemahan ini menjadi bahan evaluasi untuk memperbaiki pada pelaksanaan pemilihan umum mendatang. Untuk itulah penulis mencoba menganalisis baik dari sistem maupun pandangan dan kajian dari berbagai macam penelitian.

Sebagai negara demokrasi, Indonesia terus melakukan langkah-langkah perubahan menuju sebuah sistem pemilihan umum yang tepat mengingat wilayah yang luas dan penduduk yang banyak tersebar di berbagai pulau-pulau di Indonesia. Perubahan sistem pemilihan umum tersebut dari sistem proporsional tertutup menjadi sistem proporsional terbuka. Sistem proporsional terbuka inilah yang menjadi pilihan dalam sistem demokrasi langsung di Indonesia.

Demokrasi merupakan politik pemerintahan diri dengan kekuasaan- kekuasaan pemerintah yang dibatasi hukum dan kebiasaan untuk melindungi hak-hak perorangan warga negara. Demokrasi pada dasarnya adalah kekuasaan dari dan untuk rakyat. Demokrasi merupakan suatu bentuk atau sistem pemerintahan di mana seluruh rakyatnya ikut serta dalam memerintah, yaitu melalui perantara wakil-wakil terpilih mereka. Demokrasi merupakan suatu gagasan atau pandangan hidup yang mengutamakan persamaan hak dan kewajiban serta perlakuan yang sama bagi semua warga negaranya. Lahirnya demokrasi dari nilai-nilai yang sangat mendasar. ${ }^{3}$

Dalam sistem ketatanegaraan Indonesia, sistem pemilihan umum secara langsung, diatur menggunakan Undang-Undang No. 7 Tahun 2017 Tentang Pemilu. Undang-Undang ini menjadi dasar pelaksanaan pemilu tahun 2019 yang dilaksanakan secara serentak untuk memilih calon anggota legislatif.

Rancangan Undang-Undang Pemilu itu disetujui Rapat Paripurna Dewan Perwakilan Rakyat Republik Indonesia (DPR RI) pada 21 Juli 2017 dini hari dan selanjutnya disahkan oleh Presiden Joko Widodo pada 15 Agustus 2017. Undangundang ini terdiri atas 573 pasal, penjelasan, dan 4 lampiran. Ditegaskan dalam undang-undang ini, pemilu dilaksanakan berdasarkan asas langsung, umum, bebas, rahasia, jujur, dan adil. Dalam menyelenggarakan pemilu, penyelenggara pemilu juga

70.

${ }^{3}$ Mayo Henry B. 1960. An Introduction to Democratic Theory. New York: Oxford University Press, 
harus memenuhi prinsip: mandiri, jujur, adil, berkepastian hukum, tertib, terbuka, proporsional, profesional, akuntabel, efektif, dan efisien. ${ }^{4}$

Pemilihan umum tahun 2019 yang penulis jelaskan di atas, menggunakan sistem proporsional terbuka. Sistem proporsional terbuka ini dianggap paling demokratis bila dibandingkan dengan sistem proporsional tertutup. Rakyat dengan jelas dapat memilih siapa yang menjadi wakilnya karena terpampang dengan jelas nama dan foto orang yang dipilihnya. Berbeda dengan sistem proporsional tertutup, karena rakyat hanya memilih partai yang menjadi pilihannya.Ini berarti kontra produktif dengan asas demokrasi yang menjunjung tinggi transparansi. Masyarakat akan tahu siapa yang menjadi wakilnya di parlemen, tidak seperti istilah membeli kucing dalam karung seperti pemilu sebelum era reformasi.

Dengan adanya sistem proporsional terbuka ini, hendaknya dijadikan sebagai ajang selektivitas dalam memilih calon anggota legislatif. Tidak hanya memanfaatkan popularitas semata, tetapi harus melalui proses selektif dan memenuhi kualifikasi sebagai pemimpin. Syarat-syarat untuk menjadi calon anggota legislatif harus dikaji dan diuji supaya memiliki kapasitas dan kapabilitas sebagai anggota legislatif. Dalam hal perekrutan calon legislatif oleh partai politik pun harus mempertimbangkan dari segi pemanfaatan jangan hanya mencari popularitas dan keuntungan partai. Namun harus benar-benar memiliki kualitas.

Uraian di atas menjelaskan bahwa dalam hal perekrutan dan penyeleksian atau pun kualifikasi calon anggota legislatif yang dilakukan partai politik, penulis ingin pengkaji dan meninjau dari sudut pandang Fiqih Siyasah. Juga dalam sistem proporsional terbuka, masalah yang penulis bahas yaitu: Bagaimanakah kualifikasi calon legislatif dalam pandangan fiqih siyasah? Bagaimanakah pandangan fiqih siyasah terhadap sistem proporsional terbuka? Dalam penelitian pustaka (library research) ini bertujuan untuk: Untuk mengetahui kualifikasi calon legislatif dalam pandangan fiqih siyasah serta untuk mengetahui pandangan fiqih siyasah terhadap sistem proporsional terbuka.

\section{B. METODE PENELITIAN}

Pendekatan penelitian ini menggunakan pendekatan studi kasus. Studi kasus merupakan salah satu jenis pendekatan kualitatif yang menelaah sebuah "kasus" tertentu dalam konteks atau setting kehidupan nyata kontemporer. Peneliti studi kasus dapat memilih tipe penelitiannya berdasarkan tujuan, yakni studi kasus instrumental tunggal yang berfokus pada satu isu atau persoalan tertentu, studi kasus kolektif yang memanfaatkan beragam kasus untuk mengilustrasikan suatu persoalan penting dari berbagai perspektif, studi kasus intrinsik yang fokusnya adalah pada kasus itu sendiri, karena dianggap unik atau tidak biasa. Prosedur utamanya menggunakan sampling purposeful (untuk memilih kasus yang dianggap penting), yang kemudian dilanjutkan

${ }^{4}$ Santoso T., Budhiati I. 2019. Pemilu di Indonesia: Kelembagaan, Pelaksanaan, dan Pengawasan. Jakarta: Sinar Grafika, 10-11. 
dengan analisis holistik atas kasus tersebut melalui deskripsi detail atas pola-pola, konteks dan setting di mana kasus itu terjadi. ${ }^{5}$

Jenis penelitian ini adalah penelitian kualitatif yang bersifat studi pustaka (library research) yang menggunakan buku-buku dan literatur-literatur lainnya sebagai objek yang utama ${ }^{6}$. Jenis penelitian yang digunakan adalah kualitatif, yaitu penelitian yang menghasilkan informasi berupa catatan dan data deskriptif yang terdapat di dalam teks yang diteliti. ${ }^{7}$

Dengan penelitian kualitatif, perlu dilakukan analisis deskriptif. Metode analisis deskriptif memberikan gambaran dan keterangan yang secara jelas, objektif, sistematis, analitis dan kritis mengenai sistem proporsional terbuka dalam pandangan fiqih siyasah serta kualifikasi calon legislatif menurut fiqih siyasah. yang didasarkan pada langkah awal yang ditempuh dengan mengumpulkan data-data yang dibutuhkan, kemudian dilakukan klasifikasi dan deskripsi.

\section{ANALISIS DAN PEMBAHASAN}

\section{Sistem Pemilihan Umum}

Sistem pemilihan umum merupakan suatu komponen yang secara teratur saling berhubungan dan merupakan keseluruhan yang saling berkaitan dan bersamasama berfungsi untuk mencapai suatu tujuan tertentu. Dalam Pengantar Fungsi Sistem Pemilihan Umum Anggota Dewan Perwakilan Rakyat (DPR) dan Dewan Perwakilan Rakyat Daerah (DPRD), Ramlan Surbakti menjelaskan setidak-tidaknya terdapat dua fungsi sistem pemilihan umum. ${ }^{8}$ Pertama, sebagai prosedur dan mekanisme konversi suara pemilih (votes) menjadi kursi (seats) penyelenggara negara lembaga legislatif dan/atau lembaga eksekutif baik pada tingkat nasional maupun lokal. Prosedur dan mekanisme seperti inilah yang biasa disebut proses penyelenggaraan tahapan Pemilu. Untuk membedakan Pemilu authoritarian dari Pemilu demokratis, maka negara demokrasi menyusun undang-undang tentang pemilihan umum yang pada dasarnya merupakan penjabaran prinsip-prinsip demokrasi. Dari undang-undang Pemilu yang berisi penjabaran prinsip-prinsip demokrasi, seperti asas-asas Pemilu, Pemilu berintegritas, dan Pemilu berkeadilan, akan dapat dirumuskan sejumlah parameter untuk proses penyelenggaraan pemilu yang demokratis.

Kedua, sebagai instrumen untuk membangun sistem politik demokrasi, yaitu melalui konsekuensi setiap unsur sistem pemilihan umum terhadap berbagai aspek sistem politik demokrasi. Sistem Pemilu terdiri atas enam unsur, dan empat diantaranya merupakan unsur mutlak dan dua unsur pilihan. Keempat unsur mutlak

\footnotetext{
${ }^{5}$ Creswell J.W. 2014. "Penelitian Kualitatif dan Desain Riset, memilih diantara lima pendekatan" Yogyakarta: Pustaka Pelajar ed.3, 21.

${ }^{6}$ Sutrisno Hadi. 1995. Statistik II. Jakarta: PT. Rineka Cipta, 3.

${ }^{7}$ Mantra Bagus Ida. 2004. Filsafat Penelitian \& Metode Penlitian Sosial. Yogyakarta: Pustaka Belajar, 30.

8Pahlevi I. 2015. Sistem Pemilu di Indonesia antara Proporsional dan Mayoritarian. [ P3Di]. Jakarta: Azza Grafika, 84.
} 
tersebut adalah Besaran Daerah Pemilihan, Peserta dan Pola Pencalonan, Model Penyuaraan, dan Formula Pemilihan. Keempat nya disebut sebagai unsur mutlak karena tanpa salah satu dari keempat unsur ini ketiga unsur lain tidak akan mampu mengonversi suara pemilih menjadi kursi. Dua unsur pilihan, yaitu ambang-batas perwakilan dan waktu penyelenggaraan berbagai jenis Pemilu, dikategorikan sebagai pilihan karena, keempat unsur sistem pemilihan umum lainnya masih mampu mengonversi suara pemilih menjadi kursi, dan salah satu atau keduanya akan digunakan untuk mencapai tujuan lain yang tidak dapat dicapai dengan unsur sistem pemilihan umum lainnya. ${ }^{9}$

Sistem pemilihan umum merupakan metode yang mengatur serta memungkinkan warga negara memilih para wakil rakyat di antara mereka sendiri. Metode pemilihan berhubungan erat dengan aturan dan prosedur untuk mengubah atau mentransformasikan suara ke kursi di parlemen. Baik yang memilih maupun yang dipilih merupakan bagian dari entitas yang sama. Bagian-bagian atau komponenkomponen dalam pelaksanaan pemilihan umum diantaranya, sistem hak pilih, sistem pembagian daerah pemilihan, sistem pemilihan, dan sistem pencalonan.

Bidang ilmu politik mengenal beberapa sistem pemilihan umum yang berbedabeda dan memiliki ciri yang khas masing-masing akan tetapi, pada umumnya berpegang pada dua prinsip pokok, yaitu:

\section{a. Sistem Pemilihan Mekanis}

Pada sistem ini, rakyat dianggap sebagai suatu massa individu-individu yang sama. Individu-individu ini yang menjadi pengendali hak pilih masing-masing dalam mengeluarkan satu suara di tiap pemilihan umum untuk satu lembaga perwakilan.

\section{b. Sistem Pemilihan Organis}

Pada sistem ini, rakyat dianggap sebagai sekelompok individu yang hidup bersama-sama dalam beraneka ragam persekutuan hidup. Jadi persekutuan persekutuan inilah yang diutamakan menjadi pengendali hak pilih. ${ }^{10}$

Dari kedua prinsip pokok di atas, penulis menganggap bahwa Sistem Pemilihan Organis sangat berpengaruh terhadap perolehan suara calon atau partai politik dalam pemilihan umum. Jadi, sistem pemilihan umum adalah instrumen untuk menerjemahkan perolehan suara di dalam pemilu ke dalam kursi-kursi yang dimenangkan oleh partai politik atau calon.

Pemilihan umum (Pemilu) memiliki unsur-unsur, setiap unsur sistem pemilihan umum terdapat sejumlah pilihan, dan setiap pilihan memiliki konsekuensi terhadap berbagai aspek sistem politik demokrasi. Misalnya, Besaran Daerah Pemilihan terdiri atas dua ukuran, yaitu satu kursi per-Dapil (single-member constituency), dan

9Pahlevi I. 2015. Sistem Pemilu di Indonesia antara Proporsional dan Mayoritarian. [ P3Di]. Jakarta: Azza Grafika, 84.

${ }^{10}$ Kusnardi Moh., Harmaily Ibrahim. 1981. Pengantar Hukum Tata Negara Indonesia. Jakarta: Pusat Studi Hukum Tata Negara, Fakultas Hukum Universitas Indonesia dan CV. Sinar Bhakti, 82. 
banyak kursi per-Dapil (multi-members constituency). Banyak kursi per-Dapil dapat dibedakan menjadi tiga ukuran, yaitu Dapil Kecil 2 sampai dengan 5 kursi (Small Constituency), Dapil Sedang 6 sampai 9 kursi (Medium Constituency), dan Dapil Besar 10 atau lebih (Large Constituency). Termasuk yang terakhir ini adalah Dapil Tunggal secara Nasional (single-nation constituency), seperti yang diterapkan Negeri Belanda dan Timor Leste. Dengan kata lain, terdapat 5 pilihan untuk Besaran Daerah Pemilihan dan yang masing-masing memiliki konsekuensi terhadap sistem partai atau pun sistem perwakilan politik. Proses pembuatan undang-undang Pemilu oleh Dewan Perwakilan Rakyat (DPR) dan Pemerintah selama ini cenderung tidak memperlakukan sistem pemilihan umum secara komprehensif. ${ }^{11}$

Proses penyelenggaraan Pemilu tidak disusun berdasarkan parameter Pemilu yang jelas. Satu-satunya tahap yang diatur dengan prinsip yang jelas adalah pemungutan dan perhitungan suara di Tempat Pemungutan Suara (TPS). Prinsip yang mengatur proses pemungutan dan perhitungan suara di TPS tidak hanya enam asas Pemilu yang disebutkan dalam Pasal 22E ayat (1) Undang-Undang Dasar 1945, yaitu langsung, umum, bebas, rahasia, jujur dan adil, tetapi juga dua asas tambahan, yaitu transparan dan akuntabel. Undang-undang Pemilu mengatur soal kampanye dan dana kampanye Pemilu beserta larangan dan sanksinya. Akan tetapi karena dirumuskan tidak berdasarkan parameter Pemilu demokratis yang jelas, maka tidak hanya ketentuan tentang kampanye dan dana kampanye banyak mengandung kekosongan hukum tetapi juga mekanisme penegakan ketentuan tersebut. Lain halnya bila ketentuan kampanye dan dana kampanye tersebut berdasarkan parameter yang jelas, seperti persaingan yang bebas dan adil antar peserta Pemilu untuk meyakinkan pemilih agar memberikan suara kepada mereka, akan dapat disusun ketentuan, larangan, sangsi dan mekanisme penegakan hukum yang tepat. ${ }^{12}$

Pada tingkatan yang paling dasar, sistem pemilu mengonversi perolehan suara dalam sebuah pemilihan umum menjadi kursi-kursi yang dimenangkan oleh partai dan kandidat. Variabel-variabel kuncinya adalah rumusan pemilu yang digunakan (yakni, apakah sistem pluralitas/mayoritas, proporsional, campuran atau sistem lain yang dipakai, dan rumusan matematis apa yang dipakai untuk memperhitungkan alokasi kursi), struktur pemungutan suara (yakni, apakah pemberi suara memilih seorang kandidat atau sebuah partai dan apakah pemberi suara membuat pilihan tunggal atau mengungkapkan serangkaian preferensi) dan besaran daerah pemilihan (bukan berapa pemilih yang tinggal dalam suatu daerah pemilihan, tetapi berapa wakil di lembaga legislatif yang dipilih di daerah tersebut). Juga harus ditekankan bahwa, walaupun dalam buku panduan tidak berfokus pada aspek-aspek administratif pemilihan umum (seperti distribusi tempat pemungutan suara, nominasi kandidat, pendaftaran pemilih, siapa yang menyelenggarakan pemilihan umum dan lain sebagainya), isu-isu ini sangatlah penting, dan kelebihan potensial masing-masing

${ }^{11}$ Pahlevi I. 2015. Sistem Pemilu di Indonesia antara Proporsional dan Mayoritarian. [ P3Di]. Jakarta: Azza Grafika, 54.

12 Pahlevi I. 2015. Sistem Pemilu di Indonesia antara Proporsional dan Mayoritarian. [ P3Di]. Jakarta: Azza Grafika, 83. 
pilihan sistem pemilu yang ada akan terganggu kecuali isu-isu tersebut diberi perhatian. ${ }^{13}$

Desain sistem pemilu juga berpengaruh pada bidang-bidang lain hukum pemilu, pilihan sistem pemilu berpengaruh pada cara di mana batas-batas daerah pemilihan ditetapkan, bagaimana para pemilih didaftar, desain surat suara, bagaimana suara dihitung, dan banyak sekali aspek-aspek lain proses pemilu. ${ }^{14}$

Lembaga-lembaga politik membentuk aturan main bagaimana demokrasi dipraktikkan, dan sering dikemukakan bahwa lembaga politik yang paling mudah dimanipulasi, untuk tujuan baik atau buruk, adalah sistem pemilu. Dalam mengonversi perolehan suara dalam sebuah pemilihan umum menjadi kursi di badan legislatif, pilihan sistem pemilu bisa sangat menentukan siapa yang terpilih dan partai mana yang meraih kekuasaan. Walaupun banyak aspek kerangka politik suatu negara sering disebutkan dalam konstitusi dan oleh karena itu sulit suatu negara sering disebutkan dalam konstitusi dan oleh karena itu sulit di amandemen, perubahan sistem pemilu kerap hanya membutuhkan legislasi baru. Bahkan dengan masingmasing pemilih memberi suara yang persis sama dan jumlah suara yang persis sama untuk setiap partai, satu sistem pemilu bisa menghasilkan sebuah pemerintahan koalisi atau pemerintahan minoritas sementara sistem pemilu yang lainnya memungkinkan sebuah partai saja memperoleh kontrol mayoritas.

Sejumlah konsekuensi lain dari sistem pemilu dapat melampaui efek yang sudah disebutkan di atas. Beberapa sistem mendorong bahkan memaksakan, pembentukan partai-partai politik, sedangkan sistem-sistem lainnya hanya mengakui kandidat-kandidat perorangan. Jenis partai yang berkembang, khususnya jumlah dan ukuran relatif partai-partai politik dalam badan legislatif, sangat dipengaruhi oleh sistem pemilu. Begitu pula kohesi internal dan disiplin partai, sebagian sistem mungkin mendorong faksionalisme, di mana sayap-sayap berlainan sebuah partai terus-menerus saling bertikai, sementara sebagian sistem yang lain mungkin mendorong partai berbicara dengan suara tunggal dan mencegah perbedaan pendapat. Sistem pemilu juga bisa mempengaruhi cara kampanye partai dan cara elite politik berperilaku, dengan demikian berperan dalam menentukan iklim politik lebih luas. Sistem pemilu bisa mendorong, atau menghambat, pembentukan persekutuan antara berbagai partai di samping bisa memberi insentif bagi partai-partai maupun kelompok-kelompok untuk membuat basis lebih luas dan mengakomodasi, atau mendasarkan diri pada daya tarik sempit etnisitas atau ikatan kekerabatan. ${ }^{15}$

13 IDEA. 2005. Disain Sistem Pemilu:Buku Panduan Baru Sistem Internasional IDEA. Diterjemahkan oleh K. N. Agustyati, Electoral System Design: The New International IDEA Handbook". Swedia: International IDEA.SE - 10334 Stockholm.

${ }^{14}$ Andrew Reynolds., Reilly B., Andrew Ellis A. 2016. Desain Sistem Pemilu: Buku Panduan Baru Internasional IDEA. Swedia : International IDEA, 6.

15 IDEA. 2005. Disain Sistem Pemilu:Buku Panduan Baru Sistem Internasional IDEA. Diterjemahkan oleh K. N. Agustyati, Electoral System Design: The New International IDEA Handbook". Swedia: International IDEA.SE - 10334 Stockholm. 
Pilihan atas sistem pemilu adalah salah satu keputusan kelembagaan paling penting bagi demokrasi di mana pun. Dalam hampir semua kasus pilihan atas sistem pemilu tertentu memiliki pengaruh mendalam bagi masa depan kehidupan politik di negara bersangkutan, dan sistem politik, begitu sudah dipilih, sering kali tetap sangat konstan seiring berbagai kepentingan politik mengukuhkan diri di seputar dan merespon insentif-insentif yang ditawarkan sistem tersebut. Meski begitu, walaupun desain yang sengaja dibuat sudah semakin lazim dijumpai belakangan ini, secara tradisional jarang sekali sistem pemilu dipilih secara sadar.

\section{Kualifikasi Calon Legislatif menurut Undang-Undang}

Peraturan yang menjadi dasar persyaratan bakal calon anggota legislatif, diatur dengan Peraturan Komisi Pemilihan Umum (PKPU) Nomor 20 tahun 2019 Tentang Syarat Pencalonan Legislatif. Dalam Pasal 7 (1) dijelaskan bahwa. Bakal calon anggota DPR, DPRD Provinsi, dan DPRD Kabupaten/ Kota adalah warga negara Indonesia dan harus memenuhi persyaratan:

a. telah berumur 21 (dua puluh satu) tahun atau lebih terhitung sejak penetapan DCT;

b. bertakwa kepada Tuhan Yang Maha Esa;

c. bertempat tinggal di wilayah Negara Kesatuan Republik Indonesia;

d. dapat berbicara, membaca, dan/atau menulis dalam bahasa Indonesia;

e. berpendidikan paling rendah tamat sekolah menengah atas, madrasah aliyah, sekolah menengah kejuruan, madrasah aliyah kejuruan, atau sekolah lain yang sederajat; setia kepada Pancasila, Undang-Undang Dasar Negara Republik Indonesia Tahun 1945, Negara Kesatuan Republik Indonesia, dan Bhineka Tunggal Ika.

f. setia kepada Pancasila, Undang-Undang Dasar Negara Republik Indonesia Tahun 1945, Negara Kesatuan Republik Indonesia, dan Bhineka Tunggal Ika.

g. tidak pernah sebagai terpidana berdasarkan putusan pengadilan yang memperoleh kekuatan hukum tetap yang diancam dengan pidana penjara 5 (lima) tahun atau lebih berdasarkan putusan pengadilan yang telah berkekuatan hukum tetap;

h. bukan mantan terpidana bandar narkoba, kejahatan seksual terhadap anak, atau korupsi;

i. Sehat jasmani, rohani, dan bebas penyalahgunaan narkotika, psikotropika dan zat adiktif;

j. terdaftar sebagai pemilih;

k. bersedia bekerja penuh waktu;

1. mengundurkan diri sebagai; 1). gubernur, wakil gubernur, bupati, wakil bupati, wali kota atau wakil wali kota; kepala desa; 2). perangkat desa yang 
mencakup unsur staf yang membantu Kepala Desa dalam penyusunan kebijakan dan koordinasi yang diwadahi dalam kebijakan dan koordinasi yang diwadahi dalam Sekretariat Desa, dan unsur pendukung tugas Kepala Desa dalam pelaksanaan kebijakan yang diwadahi dalam bentuk pelaksana teknis dan unsur kewilayahan; 3). Aparatur Sipil Negara; 4). anggota Tentara Nasional Indonesia; 5). anggota Kepolisian Negara Republik Indonesia; 6). direksi, komisaris, dewan pengawas dan/atau karyawan pada Badan Usaha Milik Negara, Badan Usaha Milik Daerah, Badan Usaha Milik Desa, atau badan lain yang anggarannya bersumber dari keuangan negara;

m. mengundurkan diri sebagai Penyelenggara Pemilu, Panitia Pemilu, atau Panitia Pengawas;

n. bersedia untuk tidak berpraktik sebagai akuntan publik, advokat, notaris, pejabat pembuat akta tanah, atau tidak melakukan pekerjaan penyedia barang dan jasa yang berhubungan dengan keuangan negara serta pekerjaan lain yang dapat menimbulkan konflik kepentingan dengan tugas, wewenang, dan hak sebagai anggota DPR, DPRD Provinsi, dan DPRD Kabupaten/Kota sesuai dengan ketentuan peraturan perundang-undangan;

o. bersedia untuk tidak merangkap jabatan sebagai pejabat negara lainnya, direksi, komisaris, dewan pengawas dan/atau karyawan pada Badan Usaha Milik Negara, Badan Usaha Milik Daerah, Badan Usaha Milik Desa, atau badan lain yang anggarannya bersumber dari keuangan negara;

p. menjadi anggota Partai Politik;

q. menjadi anggota Partai Politik;

r. dicalonkan hanya di 1 (satu) lembaga perwakilan;

s. dicalonkan hanya oleh 1 (satu) Partai Politik;

t. dicalonkan hanya di 1 (satu) Dapil; dan

u. mengundurkan diri sebagai anggota DPR, DPRD Provinsi, atau DPRD Kabupaten/Kota bagi calon anggota DPR, DPRD Provinsi, atau DPRD Kabupaten/Kota yang dicalonkan oleh Partai Politik yang berbeda dengan Partai Politik yang diwakili pada Pemilu Terakhir. ${ }^{16}$

\section{Kualifikasi Calon Legislatif Menurut Fiqih Siyasah}

Pemilihan umum merupakan sarana demokrasi untuk memilih pemimpin di masyarakat. Baik itu pemimpin di lembaga eksekutif maupun di lembaga legislatif. Memilih pemimpin di lembaga legislatif baik itu di Dewan Perwakilan Rakyat Republik Indonesia (DPRRI), Dewan Perwakilan Daerah (DPD), Dewan Perwakilan Rakyat Daerah (DPRD) di Tingkat Provinsi, dan Dewan Perwakilan Rakyat Daerah di

16 KPU. 2019. Peraturan Komisi Pemilihan Umum Nomor 20 tahun 2019 Tentang Syarat Pencalonan Legislatif. Jakarta: KPU, 10. 
Tingkat Kabupaten/Kota, memerlukan pengetahuan dan pengertian yang jelas. Pengetahuan dan pengertian yang jelas ini terutama terhadap kriteria/kualifikasi calon yang akan dipilih menjadi pemimpin/anggota legislatif.

Legislatif merupakan lembaga penengah dan pemberi fatwa ( ahlul halli wa alaqdi) ${ }^{17}$ Pembicaraan sebagian ulama mempertanyakan dan meragukan siapa sebenarnya ahlul halli wa al-aqdi itu, sebab dengan penamaan ahlul halli wal aqdi tersebut, tentu menjamin akan tidak ada perselisihan dalam tubuh mereka. Namun terkadang pula mereka disebut sebagai ahlul ikhtiyar (ahli memilih pemimpin), ahlussyura (juru musyawarah/ runding), atau ahlul-ijtihad (pakar ijtihad). Beberapa ulama telah memberikan perhatian terhadap (pakar ijtihad) ahlul halli wa al-aqdi ini. Ahlul halli wa al-aqdi adalah orang-orang yang diikuti atau di patuhi dan dipercaya umat. Umat rela dengan pendapat mereka, karena mereka dikenal ikhlas, konsisten, taqwa, adil, beride baik, memahami masalah dan lebih mementingkan kepentingan umum. ${ }^{18}$

Syarat-syarat mengenai calon legislatif sudah ditentukan dengan undangundang. Namun, syarat-syarat tersebut belum bisa menjamin bahwa calon yang akan dipilih dapat menjalankan amanah dari rakyat. Untuk itu, penulis akan menjelaskan kualifikasi menurut pandangan fiqih siyasah. Kualifikasi menurut pandangan fiqih siyasah ini sangat penting, mengingat kita mencontoh dari apa yang telah di jalankan oleh Nabi Muhammad saw. dan para sahabatnya.

Proses pemilihan dan pengangkatan pemimpin pada hakikatnya untuk mengelola kehidupan kita. Hampir setiap saat kita mendengar dan mengalami proses pemilihan baik itu pemilihan calon anggota legislatif maupun pemimpin di tingkat desa, kabupaten dan kota, provinsi maupun nasional. Pelaksanaan pergantian pemimpin dari kepala desa, bupati/wali kota, gubernur hingga presiden secara periodik menunjukkan bagaimana pentingnya kepemimpinan.

Meski pun pemimpin penting adanya, namun kita tidak diperkenankan meminta sebuah jabatan (amanah) menjadi pemimpin, sebagaimana hadis berikut yang artinya:

“Diceritakan kepada kami oleh Abu al-Nu'man Muhammad ibn al-Fadhl,diceritakan kepada kami oleh Jarir ibn Hazim, diceritakan kepada kami oleh al-Hasan, diriwayatkan dari Abdul Rahman ibn Samurah r.a. katanya, Rasulullah Saw. bersabda, "Wahai Abdul Rahman bin Samurah, janganlah kamu memohon untuk menjadi pemimpin. Sesungguh nya jika kepemimpinan diberikan kepada kamu melalui permohonan, maka kamu akan dibebani tanggung jawab sebagai seorang pemimpin. Dan jika jabatan pimpinan diberikan kepada kamu tanpa melalui permohonan, maka kamu akan mendapatkan pertolongan (dukungan dalam kepemimpinan). Dan jika kamu telah melaksanakan sumpah jabatan, lalu kamu lihat ada orang lain yang lebih baik untuk jabatan itu, maka batalkanlah sumpahmu dan berikanlah (jabatan itu) kepada orang yang lebih baik itu." (H.R. al-Bukhari).

${ }^{17}$ Hikmat A. 1990. Hukum dan Konstitusi Sistem Politik Islam. Bandung: Mizan, 245.

18 Zaidan, A. K. 1984. Al-Fardu wa al-Daulah fi al-syari'ah al-Islamiyah :Masalah Kenegaraan Islam dalam Pandangan. Abd, Aziz [Penerjemah].Jakarta: Yayasan al-Amin, 26. 
Jika dikehendaki lebih komprehensif seharusnya seorang pemimpin harus memiliki empat sifat sebagai berikut:

\section{1) Shiddiq (honest/jujur),}

Shiddiq artinya benar. Bukan hanya perkataannya yang benar, tapi juga perbuatannya juga benar. Sejalan dengan ucapannya artinya sebagai orang yang mengemban amanah, kejujuran mutlak harus dimiliki oleh seorang pemimpin sebagai wakil rakyat. Karakter Nabi Muhammad saw. telah dibenarkan di dalam Q.S. al-Najm [53]: 4-5 yang artinya :"Dan tiadalah yang diucapkannya itu (al-Qur'an) menurut kemauan hawa nafsunya. Ucapannya itu tiada lain hanyalah wahyu yang diwahyukan kepadanya."

\section{2) Amannah (credible/terpercaya),}

Amannah artinya benar-benar bisa dipercaya. Jika satu urusan diserahkan kepadanya, niscaya orang percaya bahwa urusan itu akan dilaksanakan dengan sebaik-baiknya. Oleh karena itulah Nabi Muhammad Saw dijuluki oleh penduduk Mekah dengan gelar "al Amin" yang artinya "terpercaya" jauh sebelum beliau diangkat jadi Nabi. Apa pun yang beliau ucapkan, penduduk Mekah mempercayainya karena beliau bukanlah orang yang pembohong. Seperti sudah dijelaskan di dalam Q.S. al-A'raaf [7]: 68 yang artinya: "Aku menyampaikan amanat-amanat Tuhanku kepadamu dan aku hanyalah pemberi nasihat yang ter percaya bagimu." Mustahil Nabi Saw itu khianat terhadap orang yang memberinya amanah. Ketika Nabi Muhammad Saw ditawari kerajaan, harta, wanita oleh kaum Quraisy agar beliau meninggalkan tugas ilahinya menyiarkan agama Islam, beliau menjawab: "Demi Allah...wahai Paman, seandainya mereka dapat meletakkan matahari di tangan kanan ku dan bulan di tangan kiri ku agar aku meninggalkan tugas suci ku, maka aku tidak akan meninggalkannya sampai Allah memenangkan (Islam) atau aku hancur karena-Nya"

Meski kaum kafir Quraisy mengancam membunuh Nabi Saw, namun Nabi Saw tidak gentar dan tetap menjalankan amanah yang dia terima. Seorang Muslim harusnya bersikap amanah seperti Nabi. Kekuasaan itu amanah, karena itu harus dilaksanakan dengan penuh amanah. Ungkapan tersebut menyiratkan dua hal. Pertama, apabila manusia berkuasa di muka bumi, menjadi pemimpin, maka kekuasaan yang diperoleh sebagai suatu pendelegasian kewenangan dari Allah SWT. (delegation of authority) karena Allah SWT sebagai sumber segala kekuasaan. Dengan demikian kekuasaan yang dimiliki hanyalah sekadar amanah dari Allah SWT yang bersifat relatif, yang kelak harus dipertanggungjawabkan di hadapan-Nya. Kedua, karena kekuasaan itu pada dasarnya amanah, maka pelaksanaannya pun memerlukan amanah. Amanah dalam hal ini adalah sikap penuh pertanggungjawaban, jujur dan memegang teguh prinsip. Amanah dalam arti ini sebagai prinsip atau nilai. ${ }^{19}$

${ }^{19}$ Nata, A. 2006. Massail Al-Fiqhiyah. Jakarta: Kencana, 297. 


\section{3) Tabligh (accountable)}

Tabligh artinya menyampaikan. Segala firman Allah SWT yang ditujukan kepada manusia, disampaikan oleh Nabi Saw tidak ada yang disembunyikan meski itu menyinggung Nabi Saw seperti yang diterangkan dalam Q.S. al-Abasa [80]:1-2. Dalam suatu riwayat ayat ini turun berkenaan dengan Ibnu Ummi Maktum yang buta yang datang kepada Rasulullah saw. sambil berkata: "Berilah petunjuk kepadaku ya Rasulullah." Pada waktu itu Rasulullah saw. sedang menghadapi para pembesar kaum musyrikin Quraisy, sehingga Rasulullah Saw berpaling dari padanya dan tetap menghadapi pembesar-pembesar Quraisy. Ummi Maktum berkata: "Apakah yang saya katakan ini mengganggu tuan?" Rasulullah Saw menjawab: "Tidak." Ayat ini turun sebagai teguran atas perbuatan Rasulullah saw. (Diriwayatkan oleh at-Tirmidzi dan alHakim yang bersumber dari 'Aisyah. Diriwayatkan pula oleh Ibnu Ya'la yang bersumber dari Anas).

Sebetulnya apa yang dilakukan Nabi Saw itu menurut standar umum adalah hal yang wajar. Saat sedang berbicara di depan umum atau dengan seseorang, tentu kita tidak suka diinterupsi oleh orang lain. Namun untuk standar Nabi Saw, itu tidak cukup. Oleh karena itulah Allah SWT menegurnya. Sebagai seorang yang tablig, meski ayat itu menyindirnya, Nabi Muhammad Saw tetap menyampaikannya kepada kita. Itulah sifat seorang Nabi.

\section{4) Fathonah (capable/cakap).}

Fathonah artinya Cerdas. Mustahil Nabi Saw itu bodoh atau jahlun. Dalam menyampaikan 6.236 ayat al-Qur'an kemudian menjelaskan nya dalam puluhan ribu hadis membutuhkan kecerdasan yang luar biasa. Nabi Saw harus mampu menjelaskan firman-firman Allah SWT kepada kaumnya sehingga mereka mau masuk ke dalam Islam. Nabi Saw juga harus mampu berdebat dengan orang-orang kafir dengan cara yang sebaik-baiknya. Apalagi Nabi Saw mampu mengatur umatnya sehingga dari bangsa Arab yang bodoh dan terpecah-belah serta saling perang antar suku, menjadi satu bangsa yang berbudaya dan berpengetahuan dalam 1 negara yang besar yang dalam 100 tahun melebihi luas Eropa. Negara tersebut membentang dari Spanyol dan Portugis di Barat hingga India Barat.

Itu semua membutuhkan kecerdasan yang luar biasa. Bahkan Michael H Hart yang sebetulnya membenci Muslim pun menempatkan Nabi Muhammad Saw sebagai tokoh nomor 1 mengungguli Yesus dan tokoh-tokoh dunia lainnya karena prestasi Nabi Muhammad Saw yang luar biasa di bukunya yang berjudul "The 100 A Ranking of The Most Influental Persons in History", Bukan hanya dari segi agama, tapi juga dari segi dunia. Sifat-sifat inilah yang secara sempurna dimiliki oleh pemimpin agung seperti Muhammad Rasulullah Saw, dan seharusnya juga oleh para pemimpin umat/masyarakat sesuai dengan bobotnya.

Ali menjadi Khalifah Keempat (36-41 H / 656-661 M) menggantikan Khalifah Utsman melalui desakan sebagian sahabat, terutama dari para veteran Perang Badar. Selanjutnya Muawiyah bin Abi Sufyan menggantikan sahabat Ali bin Abi Thalib. 
Setelah Muawiyah bin Abi Sufyan, suksesi kepemimpinan terjadi melalui pewarisan kepada anak atau kerabat seperti lazimnya sistem monarki, suatu sistem rekrutmen kepemimpinan (suksesi) yang sejatinya tidak sejalan dengan idealitas Islam. Dalam tulisan ini, penulis ingin menjelaskan dan menegaskan pentingnya pemimpin amanah. Karena amanah adalah salah satu sifat Nabi saw. selain shidiq, tablig, dan fathonah. Selain itu, amanah juga menjadi sifat pemimpin yang tercantum dalam Q.S. al-Nisa [4]:58:

“Sungguh, Allah menyuruhmu menyampaikan amanat kepada yang berhak menerimanya, dan apabila kamu menetapkan hukum di antara manusia hendaknya kamu menetapkannya dengan adil. Sungguh, Allah sebaik-baik yang memberi pengajaran kepadamu. Sungguh, Allah Maha Mendengar, Maha Melihat."

Berkaitan dengan penjelasan ayat di atas, Ahmad bin Mustafa al-Maraghi menerangkan bahwa amanah, sedikitnya ada tiga jenis: amanah seorang hamba kepada Tuhannya, amanah seseorang kepada orang lain, dan amanh kepada diri sendiri. Amanah yang pertama meniscayakan kepatuhan seseorang untuk menjaga perjanjian antara dirinya dengan Tuhannya, yang kedua dengan menepati janji dan menjaga kepercayaan orang lain, sedang yang ketiga memilih yang terbaik bagi diri sendiri. ${ }^{20}$

Ayat di atas juga menunjukkan kepada kita pentingnya memilih pemimpin yang amanah. Adapun perwujudan dari pemimpin yang amanah, sebagaimana diterangkan dalam ayat, adalah yang adil dalam menetapkan hukum dan tidak bersikap diskriminatif. Adapun tiga kriteria pemimpin yang amanah dijelaskan oleh Rasulullah saw. sebagai berikut:

Pertama; Seseorang yang tidak terlalu berambisi menduduki jabatan itu, apalagi sampai menghalalkan segala cara demi mendapatkan kekuasaan atau jabatan. Hal ini sesuai dengan hadis sahih yang diriwayatkan Abu Musa al-Asy'ari, Rasulullah bersabda:

Abu Musa berkata, "Suatu ketika aku menghadap Nabi saw. Bersama dua orang dari kaumku. Salah satu dari mereka berkata: "Wahai Rasul, angkatlah aku jadi pemimpin." Dan seorang lagi juga mengatakan hal yang sama. Kemudian Rasulullah saw. Bersabda: "Sesungguhnya kami tidak akan menyerahkan kepemimpinan ini kepada orang yang memintanya, dan tidak pula kepada yang berambisi untuk meraihnya. (H.R. Bukhari)

Dari hadis ini, kita mendapat pelajaran bahwa memberikan amanah (hak pilih) kepada orang meminta saja tidak diperkenankan, apalagi ketika seseorang yang menggunakan segala cara untuk memperoleh seb1uah jabatan, seperti misalnya dengan suap dan lain sebagainya. Jelas hal ini adalah haram. Sosok calon pemimpin yang seperti ini jelas akan sulit berlaku amanah.

Seorang calon pemimpin yang curang dan sangat berambisi, sulit untuk diharapkan akan berkorban untuk kesejahteraan rakyat. Ia justru akan sibuk

${ }^{20}$ NU On Line. 2014. Khilafah Dalam Pandangan NU. Muktamar NU Jakarta 1-2 November 2014. https://islam.nu.or.id/post/read/55557/khilafah-dalam-pandangan-nu.html [4 Maret 2020 09.15 WIB] 
memperkaya diri, mengembalikan modal, dan mencari privilage dari jabatan yang diembannya.

Kedua; Kriteria pemimpin yang amanah sebagaimana yang diajarkan Rasulullah Saw adalah seseorang yang taat ibadah, memiliki kapabilitas dalam memimpin, dan mempunyai relasi sosial yang baik dengan masyarakat. Teladan seperti ini dapat kita cari dari sepenggal kisah Umar bin Khattab, yaitu ketika ia menjadi khalifah menggantikan Abu Bakar bin Ash. Di suatu kesempatan, Umar bin Khattab mengangkat Nafi' bin al-Harits sebagai Gubernur Mekah. Sebagai Gubernur, Nafi' memilih Ibnu Abza untuk menjadi pemimpin di suatu distrik di daerah lembah dekat Mekah. Padahal semua orang tahu bahwa Ibnu Abza bukanlah dari suku yang terhormat. Ia hanyalah bekas budak di komunitas tersebut. Saat Umar bin Khattab menginformasikan hal tersebut, Nafi' bin al-Harits, menjawab: "Ia memang bekas budak, tetapi ia hafal al-Qur'an, paham masalah waris (faraidh), dan dapat memutuskan persoalan masyarakat dengan adil." Atas keputusan Nafi', Umar bin Khattab pun memujinya karena melihat kapabilitas dan keadilannya. Kisah ini dapat ditemukan dalam musnad Imam Ahmad.

Ketiga; Pemimpin yang amanah adalah seseorang yang dalam kesehariannya tidak bermewah-mewahan dan hidup sederhana sesuai kebutuhannya. Pemimpin yang hidup sederhana dapat imun (tahan) terhadap godaan kemewahan dunia. Sebaliknya, gaya hidup mewah dapat menjerumuskan seorang pejabat untuk melakukan korupsi meskipun gajinya sudah lebih dari cukup. Ancaman Nabi saw. Terhadap pejabat yang korup sebagaimana dapat kita lihat dari hadis di bawah ini:

"Tidakkah seorang hamba pun yang diberi amanah oleh Allah untuk memimpin bawahannya yang pada hari kematiannya ia masih berbuat curang atau menipu rakyatnya, melainkan Allah mengharamkan surga atasnya.

Itulah kriteria pemimpin amanah yang perlu kita refleksikan agar dapat menjadi pemimpin ataupun memilih pemimpin yang sesuai ajaran Rasulullah saw.

Nahdlatul Ulama dalam Musyawarah Nasional Alim Ulama yang diadakan di Jakarta pada tanggal 1-2 November 2014 memutuskan beberapa poin penting sehubungan dengan kepemimpinan (khilafah), yaitu:

1) Islam sebagai agama yang komprehensif (din syamil kamil) tidak mungkin melewatkan masalah negara dan pemerintahan dari agenda pembahasannya. Kendati tidak dalam konsep utuh, namun dalam bentuk nilai-nilai dan prinsipprinsip dasar (mabadi asasiyyah). Islam telah memberikan panduan (guidance) yang cukup bagi umatnya.

2) Mengangkat pemimpin (nashb al-imam) wajib hukumnya, karena kehidupan manusia akan kacau (fawdla/Chaos) tanpa adanya pemimpin. Hal ini diperkuat oleh pernyataan para ulama terkemuka, antara lain:

a) Hujjat al-Islam Abu Hamid al-Ghazali dalam Ihya' 'Ulum al-Din:

"Agama dan kekuasaan negara adalah dua saudara kembar. Agama merupakan fondasi, sedangkan kekuasaan negara adalah pengawalnya. Sesuatu yang tidak memiliki 
fondasi, akan runtuh, sedangkan sesuatu yang tidak memiliki pengawal, akan tersiasiakan"

b) Syaikh al-Islam Taqi al-Din Ibn Taimiyyah dalam as-Siyasah al Syar'iyyah fi Ishlah al-Ra'i wa al-Ra'iyyah:

"Sesungguhnya tugas mengatur dan mengelola urusan orang banyak (dalam sebuah pemerintahan dan negara) adalah termasuk kewajiban agama yang paling agung. Hal itu disebabkan oleh tidak mungkinnya agama dapat tegak dengan kokoh tanpa adanya dukungan negara"

Islam tidak menentukan apalagi mewajibkan suatu bentuk negara dan sistem pemerintahan tertentu bagi para pemeluknya. Umat diberi kewenangan sendiri untuk mengatur dan merancang sistem pemerintahan sesuai dengan tuntutan perkembangan kemajuan zaman dan tempat. Namun yang terpenting suatu pemerintahan harus bisa melindungi dan menjamin warganya untuk mengamalkan dan menerapkan ajaran agamanya dan menjadi tempat yang kondusif bagi kemakmuran, kesejahteraan, dan keadilan. Khilafah sebagai salah satu sistem pemerintahan adalah fakta sejarah yang pernah dipraktikkan oleh al-Khulafa' al-Rasyidin. Al-Khilafah al-Rasyidah adalah model yang sangat sesuai dengan eranya; yakni ketika kehidupan manusia belum berada di bawah naungan negara-negara bangsa (nation states). Masa itu umat Islam sangat dimungkinkan untuk hidup dalam satu sistem khilafah. Pada saat umat manusia bernaung di bawah negara-negara bangsa (nation states) maka sistem khilafah bagi umat Islam sedunia kehilangan relevansinya. Bahkan membangkitkan kembali ide khilafah pada masa kita sekarang ini adalah sebuah utopia. $^{21}$

Prinsip kedaulatan rakyat diimplementasikan dalam Pemilu. ini, di mana kekuasaan tertinggi Negara Indonesia ini ada di tangan rakyat. Artinya bahwa, kedaulatan rakyat adalah suara rakyat dan kemaslahatan mereka yang harus menjadi acuan tertinggi bagi setiap kebijakan pemerintah dan negara, bukan kepentingan segelintir orang yang berkuasa. Ini sejalan dengan konsep kekuasaan yang diajarkan Islam, yang tidak dimaksud lain kecuali untuk mewujudkan dan melindungi kebaikan (kemaslahatan) segenap rakyat.

Untuk menegakkan keadilan dan mewujudkan kedamaian di tengah-tengah masyarakat menuju kesejahteraan masyarakat itu berdasarkan pada doktrin agama itu sendiri. Islam mengajarkan umatnya untuk berpegang teguh pada nilai-nilai tawasuth (moderat), tasamuh (toleran), tawazun (harmonis-berimbang), dan i'tidal (luruskonsisten). Nilai-nilai inilah yang menjadikan umat Islam, terutama para ulamanya, selalu hadir dalam menciptakan kemaslahatan. Allah berfirman dalam Q. S. al-Baqarah [2] : 143:

"Dan demikian (pula) Kami telah menjadikan kamu (umat Islam) umat yang adil dan pilihan agar kamu menjadi saksi atas (perbuatan) manusia dan agar Rasul (Muhammad) menjadi saksi atas (perbuatan) kamu."

${ }^{21}$ NU On Line. 2014. Khilafah Dalam Pandangan NU. Muktamar NU Jakarta 1-2 November 2014. https://islam.nu.or.id/post/read/55557/khilafah-dalam-pandangan-nu.html [4 Maret 2020 09.15 WIB] 
Untuk menjadi saksi disyaratkan adanya kehadiran (hudlur). Artinya, harus ada keterlibatan secara aktif dalam proses sejarah kehidupan sehingga spiritualitas Islam sebagai agama yang rahmatan lil 'alamin (menjadi rahmat bagi seluruh alam) bisa mewujud dan mengada dalam bentuk kepedulian terhadap penyelesaian persoalan yang menyelimuti masyarakat. Seorang saksi tidak bisa hanya bertindak sebagai penonton. Ia punya hak untuk mengawal, mengarahkan dan mengoreksi segala apa yang disaksikan demi kemaslahatan yang bertumpu pada perlindungan agama, jiwa, akal, keturunan dan harta.

Tentang syarat-syarat yang harus dipenuhi oleh anggota ahlul halli wa al -aqdi, Mawardi berpendapat, untuk dapat menjadi anggota ahlul halli wa al-aqdi seseorang harus memenuhi tiga kriteria sebagai syarat, yaitu:

1) Mempunyai kredibilitas dan keseimbangan yang memenuhi semua kriteria. Yaitu kepercayaan masyarakat atas dirinya bahwa ia benar-benar mempunyai kemampuan secara umum dan memiliki karakter yang baik yang meliputi sifat dan sikap dalam kehidupan sehari-hari .

2) Mempunyai ilmu pengetahuan yang membuatnya mampu mengetahui siapa yang berhak dan pantas untuk memangku jabatan kepala negara dengan syarat-syaratnya.

3) Mempunyai pendapat yang kuat dan hikmah yang membuatnya dapat memilih siapa yang paling pantas untuk diberi amanat memangku jabatan kepala negara dan siapa yang paling mampu dan pandai dalam membuat kebijakan yang dapat mewujudkan kemaslahatan umat.

Pada masa Rasulullah Muhammad Saw, ahlul halli wa al-aqdi adalah para sahabat, yaitu mereka yang diserahkan tugas-tugas keamanan dan pertahanan serta urusan lain yang berkaitan dengan kemaslahatan umum, para pemuka sahabat yang sering beliau mengajak musyawarah, mereka yang pertama-tama masuk Islam (alSabiqun al-Awwalun), para sahabat yang memiliki kecerdasan dan pandangan luas serta menunjukkan pengorbanan dan kesetiaan yang tinggi terhadap Islam, dan mereka yang sukses melaksanakan tugasnya baik dari kaum Anshar maupun dari kaum Muhajjirin. Jadi jelas bahwa pada zaman itu, orang- orang yang disebut sebagai ahlil halli wa al-aqdi secara terus menerus memegang kedudukan yang sangat dipercaya selama jangka waktu lama dan dengan demikian diberi hak untuk mengambil keputusan-keputusan bersama mengenai semua masalah penting yang menyangkut umat.

\section{KESIMPULAN}

Sistem proporsional terbuka merupakan sistem pemilihan umum yang paling demokratis dalam sistem demokrasi di Indonesia. Demokrasi dalam pandangan Islam adalah musyawarah mufakat sesuai dengan Q.S. Asy-Syura [42]: 38 untuk memutuskan atau menentukan sebuah keputusan/kebijakan (ijtihad). Undang-Undang No. 7 Tahun 2017 Tentang Pemilu, merupakan ijtihad bersama untuk menentukan sistem pemilihan umum yang tepat yang dilaksanakan pada tahun 2019. Sistem 
proporsional terbuka, dinilai lebih adil dan lebih transparan jika dibandingkan dengan sistem proporsional tertutup. Dalam sistem proporsional terbuka, jumlah kursi di parlemen sudah ditetapkan sesuai dengan porsi masing-masing daerah pemilihan (Dapil). Dalam proses pemungutan suara, suara yang terbuang dapat diminimalisir sehingga calon yang terpilih mendapat legitimasi dari rakyat.

Pandangan fiqih siyasah mengenai kualifikasi calon legislatif yang dituangkan dalam Peraturan Komisi Pemilihan Umum Nomor 20 Tahun 2019 Tentang Persyaratan Calon Legislatif, bila mengacu kepada syarat-syarat yang harus dipenuhi oleh anggota ahlul halli wal aqdi, Mawardi berpendapat, untuk dapat menjadi anggota ahlul halli wal aqdi seseorang harus memenuhi tiga kriteria sebagai syarat, yaitu: 1). Mempunyai kredibilitas dan keseimbangan yang memenuhi semua kriteria. Yaitu kepercayaan masyarakat atas dirinya bahwa ia benar-benar mempunyai kemampuan secara umum dan memiliki karakter yang baik yang meliputi sifat shiddiq (honest/jujur), amanah (credible/terpercaya), tablig (accountable), fathonah (capable/cakap), yang tercermin dalam sikap kehidupan sehari-hari; 2). Mempunyai ilmu pengetahuan yang luas yang tersimpul di dalam basthothan fil ilmi wal jismi (Q.S: al-Baqarah [2]: 247) yang membuatnya mampu mengetahui siapa yang berhak dan pantas untuk memangku jabatan kepala negara dengan syarat-syaratnya; 3). Mempunyai pendapat yang kuat dan hikmah yang membuatnya dapat memilih siapa yang paling pantas untuk diberi amanat memangku jabatan kepala negara dan siapa yang paling mampu dan pandai dalam membuat kebijakan yang dapat mewujudkan kemaslahatan umat.

\section{REFERENSI}

Andrew, Reynolds., Reilly B., Andrew Ellis A. 2016. Desain Sistem Pemilu: Buku Panduan Baru Internasional IDEA. Swedia : International IDEA.

Creswell, J.W. 2014. "Penelitian Kualitatif dan Desain Riset, memilih di antara lima pendekatan" Yogyakarta: Pustaka Pelajar ed.3

Hadi, Sutrisno. 1995. Statistik II. Jakarta : PT. Rineka Cipta

Hikmat, A. 1990. Hukum dan Konstitusi Sistem Politik Islam. Bandung: Mizan

IDEA. 2005. Disain Sistem Pemilu:Buku Panduan Baru Sistem Internasional IDEA. Diterjemahkan oleh K. N. Agustyati, Electoral System Design: The New International IDEA Handbook". Swedia: International IDEA.SE - 10334 Stockholm.

KPU. 2019. Peraturan Komisi Pemilihan Umum Nomor 20 tahun 2019 Tentang Syarat Pencalonan Legislatif. Jakarta: KPU.

Kusnardi Moh., Harmaily Ibrahim. 1981. Pengantar Hukum Tata Negara Indonesia . Jakarta: Pusat Studi Hukum Tata Negara, Fakultas Hukum Universitas Indonesia dan CV. Sinar Bhakti

Mantra Bagus Ida. 2004. Filsafat Penelitian \& Metode Penlitian Sosial. Yogyakarta: Pustaka Belajar. 
Mayo Henry B. 1960. An Introduction to Democratic Theory. New York: Oxford Univercity Press

Nata, A. 2006. Massail Al-Fiqhiyah. Jakarta: Kencana.

NU On Line. 2014 .Khilafah Dalam Pandangan NU. Muktamar NU Jakarta 1-2 November 2014. https://islam.nu.or.id/post/read/55557/khilafah-dalam pandangan-nu.html [4 Maret 2020 09.15 WIB]

Pahlevi I. 2015. Sistem Pemilu di Indonesia antara Proporsional dan Mayoritarian. [ P3Di]. Jakarta: Azza Grafika

Santoso, T., Budhiati I. 2019. Pemilu di Indonesia: Kelembagaan, Pelaksanaan, dan Pengawasan. Jakarta: Sinar Grafika

Zaidan, A. K. 1984. Al-Fardu wa al-Daulah fi al-syari'ah al-Islamiyah :Masalah Kenegaraan Islam dalam Pandangan. Abd, Aziz [Penerjemah].Jakarta: Yayasan al-Amin 